\title{
The Nomadic War Machine in Jack Kerouac's Vanity of Duluoz and On the Road
}

https://doi.org/10.33806/ijaes2000.21.2.6

\author{
Sonia Kherif and Samira Al-Khawaldeh \\ University of Jordan, Jordan
}

\begin{abstract}
This study inquiries into Jack Kerouac's Vanity of Duluoz (1968) and On the Road (1957) from the perspective of Gilles Deleuze and Félix Guattari's nomadic war machine. It shifts from a rigorous scrutiny of Vanity of Duluoz for its general account of the Duluoz legend, Kerouac's alter ego, to the study of On the Road for its more specific narrative of a certain period in Kerouac's life. Being an iconic figure of rebellion and non-conformity in capitalist America during the postwar era, Kerouac's literary works have a certain social and political magnitude that falls within the discourse of deconstructing orthodoxy and dogma. The study elucidates how Kerouac's characters subvert the social norms and the state's institutions in order to break free from prestructured beliefs. The thesis of the article is to corroborate that such non-conformity and insubordination, exemplified in Kerouac's autobiographical works, align with the nomadic characteristic of Deleuze and Guattari's war machine. By extension, it aims at presenting Kerouac as the Deleuzoguattarian nomad who creates nomadic characters that deterritorialize post-war America from within.
\end{abstract}

Keywords: Deleuze and Guattari, deterritorialization, Kerouac, nomad, war machine.

\section{Introduction}

The concept of non-conformity has been prevalent throughout history, since the "I think" in Descartes' famous axiom, and Kant's demarcation of the Enlightenment, whereby many philosophers have theorized it through their varied outlooks, notably Ralph Waldo Emerson, Henry David Thoreau, and Friedrich Nietzsche. Similarly, Gilles Deleuze and Félix Guattari bring forth a social and political theory concerning a certain non-conformist force outside the state apparatuses. In Thousand Plateaus (1980), Deleuze and Guattari argue that this force, which they designate as the war machine, concocts critical thinking and rebellion. They, in effect, proceed with Michel Foucault's discourse of resistance, as Saul Newman asserts, attempting to provide an elucidation of his concept "state "capture" (2001: 97). As such, there is also affinity between Foucault, Deleuze and Guattari's discourse and Nietzsche's in which he proclaims that "the state is called the coldest of all cold monsters. Coldly lieth it also, and this lie creepeth from its mouth: 'I, the state, am the people"' (1885: 45). The action of resistance through the war machine is political and social when it comes to opposing the structural and coded orders of the state and its society. This force is subversive towards dictatorial and capitalist states that attempt to capture or appropriate assemblages 
to have power. Deleuze and Guattari's war machine, to quote Andrea Thoma, is a concept that suggests "a rebellious strategy against the state and its involvement in capitalist control systems" (2019: 1). Rebellion, as such, is a deterritorialization of the state apparatus and its society as a way to overcome regimentation. This study aims to read Kerouac's literary works, namely Vanity of Duluoz (1968) and On the Road (1957), through Deleuzoguattarian war machine. Starting this study with Vanity of Duluoz, though it chronologically succeeds On the Road, is favorable for its general account of Kerouac's pre-Beat life while On the Road tackles Kerouac's association with the Beat movement. This essay hitherto suggests that by morphing into the war machine, Kerouac and his characters undergo nomadic becoming, resulting in deterritorialization of capitalism and society through wittingly or unwittingly disseminating social and political awareness in his novels.

\section{The nomadic war machine}

The intention of the war machine is not war or armed conflict in particular but a force that is outside the control of the state and its paradigms. Deleuze and Guattari describe the war machine as "irreducible to the State apparatus, to be outside its sovereignty and prior to its law: it comes from elsewhere" (1980: 352). The war machine, as 'an assemblage', is originally reproduced by the nomad who is regarded as an outsider, or the 'other'. For Deleuze and Guattari, the war machine is essentially of another nature and origin "than the State apparatus" (1980: 352). To explain the comparative relation between the war machine and state apparatus, Deleuze and Guattari provide an example regarding an analogy of games: Chess and Go. They contend that while Chess is "structural" (1980: 353), Go is in a constant metamorphosis, which depends on various situations. In others words,

Chess pieces are coded; they have an internal nature and intrinsic properties from which their movements, situations, and confrontations derive. They have qualities; [...] Go pieces, in contrast, are pellets, disks, simple arithmetic units, and have only an anonymous, collective, or thirdperson function $[\ldots]$ Go pieces are elements of a nonsubjectified machine assemblage with no intrinsic properties, only situational ones. Thus the relations are very different in the two cases. (Deleuze and Guattari 1980: $352-53)$

This is how Deleuze and Guattari see the war machine (Go) in relation to state apparatus (Chess). The war machine cannot be controlled easily or put in defined structural strata because it owns a "power of metamorphosis" (Deleuze and Guattari 1980: 437), constantly shifting from one body to another.

However, what if this machine is captured by the state? In this respect, Deleuze and Guattari ascertain that "States have always appropriated the war machine in the form of national armies that strictly limit the becomings of the warrior" (1980: 248). If the state captures the war machine, exemplified in an autonomous warrior or individual, it thwarts the process of metamorphoses (as in 
the game of $\mathrm{Go}$ ) and he is morphed into a governed soldier. If the state is able to capture the war machine, the latter uses its aptitude to create a line of flight. Accordingly, Leonard C. Hawes estimates that the assemblage, under the control of the state, becomes rather destructive and ultimately "fails as a war machine" (2015: 88). While war is the exact aspiration of the state in appropriating the war machine, the latter, according to Paul Patton, has no relation with actual war, for it "is betrayed by its name" (2000: 109). Therefore, war happens only when the state dominates or attempts to control the war machine.

Deleuze and Guattari associate the war machine with nomad thought for its deterritorialization of spaces and edifices. They define deterritorialization as a "movement by which 'one' leaves territory" (1980: 530). Patton adds that such territory can be "conceptual, linguistic, social, or affective" (2010: 52). For Deleuze and Guattari, the nomad deterritorializes the established order while he is able to generate the war machine:

The nomads invented a war machine in opposition to the State apparatus. History has never comprehended nomadism, the book has never comprehended the outside. The State as the model for the book and for thought has a long history [...]. The State's pretension [is] to be a world order, and to root man. The war machine's relation to an outside is not another "model"; it is an assemblage that makes thought itself nomadic (1980: 24).

Here, Deleuze and Guattari contend that the state ensures the establishment of 'global' paradigms as models, which ultimately become the center. As opposed to structural oneness, Deleuze and Guattari propose the rhizome, which owns manifold principles: connection, heterogeneity, and multiplicity (1980: 7, 8). Rhizome is an "acentered [and] nonhierarchical" system (Deleuze and Guattari 1980:21) that has no beginning or end for it comprises of a line or a middle (Deleuze and Guattari 1980: 25). The state, being central whereby its coded schemes become global, thwarts the emergence of the outsider: in this case the nomadic assemblage. Deleuzoguattarian nomadism, as a form of thought, is not defined or coded by the state; rather, it is rhizomatic whereby it creates a line of flight away from the state apparatuses. Subsequently, the war machine is originated from nomadism (Deleuze and Guattari 1980: 230), because, as Christopher Miller puts it, "nomad thought is presented [...] as a remedy, a cure for the ills attendant to capitalism, among which is identity" (1993: 8).

\section{Deterritorializing static institutions in Vanity of Duluoz}

In the light of the nomadic war machine and countercultural movements, Patton maintains that "assemblages of war machine type support all those processes that remain outside the forms of state and all those movements that resist the process of capture" (2000: 111). In fact,

Every time there is an insurgency of some kind against the state, whether this takes the form of revolution, riot, guerrilla warfare or civil 
disobedience, 'it can be said that war machine has revived, that a new nomadic potential has appeared' [...] (Deleuze and Guattari 386). (2000: 111)

In this regard, one may find the countercultural movements of the midtwentieth century suitable for Patton's argument as they maintain racial, political, and literary protests against the state and its structural systems. These oppositions to the state came from the general dissatisfaction with capitalism and its repression of heterodox thinking through its 'global norms' that were implicitly or explicitly imposed on people. The most notable countercultural movement of the twentieth century is the Beat Generation, designated as literary and artistic movement. Its most prominent figures are Jack Kerouac, Allen Ginsberg, and William Burroughs. Kerouac, full name Jean-Louis Lebris de Kerouac, is an influential Beat figure who created a philosophy outside the conventional norms of modern reality. His novel Vanity of Duluoz: An Adventurous Education, 19351946 is considered a semi-autobiographical work that depicts the adventures of Jack Duluoz, the alter-ego of Kerouac. It includes reminiscences from his high school days, his college life, to his very beginnings with the Beat movement. The fictional name Jack Duluoz is mainly inspired by his real name, which is particularly mentioned in Vanity of Duluoz, declaring "My name is Jack ('Duluoz') [sic] Kerouac" (Kerouac 1968: 7). Kerouac originally intended to release all his books under the name of Jack Duluoz in a Proustian model; he, however, died before fulfilling his literary goal.

Deleuze and Guattari occasionally refer to Kerouac in several of their works, particularly in Anti-Oedipus: Capitalism and Schizophrenia where they employ psychoanalytic theory against itself. Using the title 'Anti-Oedipus' is Deleuze and Guattari's process to provide "a reading of psychoanalysis that constantly threatens to undermine its own internal coherence" (Elliott 1994: 156). They assert that artists like Kerouac "know how to leave, to scramble the codes, to cause flows to circulate, to traverse the desert of the body without organs. They overcome a limit, they shatter a wall, the capitalist barrier." (1972: 132-33). Deleuze and Guatttari, on the one hand, establish that artists like Kerouac deterritorialize capitalism; on the other hand, however, they construe that these artists

fail to complete the process, they never cease failing to do so. The neurotic impasse again closes-the daddy-mommy of oedipalization, America, the return to the native land-or else the perversion of the exotic territorialities, then drugs, alcohol-or worse still, an old fascist dream. (1972: 133)

Here, the process, Jeffrey Bjorn Falla argues, runs into continuous disruptions or "explosions" (2000: 254) as drugs or oedipal relations. Such failure of the process, notes Falla, is "not a defeat, nor is failure completely a botched attempt at emancipation. Failure, more precisely, involves the inescapability of capitalism's oedipalized commodity form" (2000: 254). Capitalism, in other words, deterritorializes "bourgeois cultural forms and moral codes, replacing 
these with the exchangeability and anonymity of the commodity form" (Elliott 1994: 157). While capitalism deterritorializes previous economic and cultural systems in order to reterritorialize them with commodity form, aiming at profit, the nomad, however, "deterritoriliazes without reterritorializing"; he "may be in position to disrupt capitalism" (Fackenthal 2019: 66). Although Deleuze and Guattari's argument of the process's failure is, more or less, accurate, this article, however, sheds light on Kerouac's deterritorialization of capitalism and becoming a nomad through the war machine. Unlike capitalism's reterritorialization, Kerouac, like the Deleuzoguattarian nomad, disrupts capitalism and does not attempt to create his system to replace what he deterritorializes.

From the very beginning of Vanity of Duluoz, Kerouac critiques the changing of the times and expresses his pessimism towards the post-war America:

$[\mathrm{M}] \mathrm{y}$ anguish as I call it arises from the fact that people have changed so much [...]. Nowadays, tell me, what is this slouching stroll people have? Is it because they're used to walking across the parking-lots only? Has the automobile filled them with such vanity that they walk like a bunch of lounging hoodlums to no destination in particular? (1968: 3)

Modern society, with its incessant distractions, its whirl of pleasures, and a sphere of continual circulation results in the drastic change epitomized in people's aversion to simple ecstasies of life. The automobile is a synecdoche for the modernization and industrialization of twentieth century America. Kerouac, thus, is "shatter[ing] a wall" of capitalism (Deleuze and Guattari 1972: 133). Interestingly enough, from the narrator's tone, one can perceive his promptness to dichotomize himself from modern society. He is disentangling himself from the purposeless masses that are lost in the marvels of the industrial and modern world and this discourse correspondingly denotes Max Stirner's 'insurrection'.

In the Oxford dictionary, insurrection means "a situation in which a large group of people try to take political control of their own country with violence" and its equivalent can be uprising or revolution. Stirner differentiates between revolution and 'insurrection' stating that while "the former consists in an overturning of conditions, of the established condition or a status, the State society, and is accordingly a political or social [sic] act" (1844: 316$)$, the latter mainly "leads us no longer to let ourselves be arranged, but to arrange ourselves, and sets no glittering hopes on institutions. It is not a fight against the established, since if it prospers, the established collapses of itself; it is only a working forth of me out of the established" (1844: 316). In relation to the war machine, 'insurrection' is a deed that differentiates the individual from the society or the state. Furthering the chasm between an individual and the state is in itself an act of insubordination because, like the nomadic war machine, it simply calls for an alternate trajectory in order to stop desiring or needing the state. 'Insurrection', on an individual level, does not call for war or armed rebellion, but it concerns itself with self-sufficiency. In the same sense, the war machine, which can be on an individual or collective level, is not a military assemblage but it holds a power of 
metamorphosis that calls for self-sufficiency and extracting one's self from a territory rather than relying on the governed institutions. This can be detected when Duluoz continues critiquing the consumer society and revealing his disenchantment with its modernization, stating that "not only because everybody drives a car and goes with stupid erect head guiding the idiot machine through the pitfalls and penalties of the traffic, but because nowadays no one walks with unconcern, head down, whistling" (1968: 4). Here, Duluoz deplores the loss of spontaneity and simplicity that are denatured by consumerism.

Socially speaking, Erik Mortenson delineates that "The Beats were seen as direct threats to both social and literary propriety. The Beat lifestyle [...] was a clear rejection of the middle-class consumerist lifestyle of 1950s" (2018: 2). Kerouac focuses on his disenchantment with the modern consumer society through referring to machines like cars and television:

I'm writing this what possible feeling can be left in me for an 'America' that has become such potboiler of broken convictions, messes of rioting and fighting in streets, hoodlumism, cynical administration of cities and states, suits and neckties the only feasible subject, grandeur all gone into the mosaic mesh of Television [...], where people screw their eyes at all those dots and pick out hallucinated images of their own contortion and are fed ACHTUNG! ATTENTION! ATENCION! [sic] (1968: 97)

The narrator, with discernible disappointment, illustrates people's carelessness toward creating a better society when he alludes to "the hallucinated images" of television, which, for Duluoz/Kerouac, are simply a capitalist tool to indoctrinate and subordinate people. This manifests the newly emerging philosophy of Kerouac as a student and his alienation from society whereof he gradually turns into an insurrectionary in the consumer society that renders people as static machines.

Further, Duluoz calls to one's mind the Orwellian world when he sets forth that "everybody dressed alike looking around everywhere at everybody with those curious new eyes of the second part of this century" (1968: 98). Through Duluoz, Kerouac implicitly contends that conformity becomes the ultimate ailment of modern society. This evidences Kerouac's affinity with Emerson, Thoreau, and Nietzsche who vigorously address the issue of the masses' blind conformity. More specifically, Emerson critiques such conformity, in "The American Scholar" (1837), writing "men in the world of to-day are bugs, are spawn, and are called "the mass' and 'the herd"' (1893: 39). Emerson brings forth the individual attitude of "Man Thinking" (1893: 23) that is able to create his own rules (like the Deleuzoguattarian nomad) and he is quite different from the masses and 'herds'. Additionally, in his "Self-reliance" (1841), Emerson introduces the concept of self-reliance-which can be aligned with Striner's 'insurrection'- clarifying that "Whoso would be a man must be a nonconformist. He who would gather immortal palms must not be hindered by the name of goodness, but must explore if it be goodness. Nothing is at last sacred but the integrity of your mind" (1893: 
52). Quite similar to Emerson's discourse, Nietzsche introduces the 'Superman', who transforms and transcends disagreeable realities, in Thus Spoke Zarathustra; he calls the masses as "herd" (1881: 11). Nietzsche maintains that "Companions the creator seeketh, not corpses - and not herds or believers either" (1881: 17). Here, herds and believers are those who haphazardly accept inured norms. Thereby, Nietzsche focuses on the importance of a person's individualism and authenticity rather than being a believer or part of the herd. Like Emerson's 'Man Thinking', Nietzsche's 'Superman' has the ability to form his own reality. Throughout the novel, Kerouac incessantly mentions and quotes Thoreau who is the embodiment of insubordination (1968: 29, 53). In "Civil Disobedience", Thoreau argues that "A wise man will only be useful as a man, and will not submit to be "clay"" (1949: 263). Thoreau, as such, believes that an individual needs to be self-reliant, independent and dissident. He further elucidates this point: "If a man is thought-free, fancy-free, imagination-free [...], unwise rulers or reformers cannot fatally interrupt him" (1949: 279). Correspondingly, Kerouac cherishes his individuality and caustically demands "Did I come to this world thru the womb of my mother the earth just so I could talk and write like everybody else?" (1968: 53). Kerouac effectively highlights his discontent with the masses' lack of originality and how conformity proliferates among Americans in the postwar era.

Excoriating society and showcasing its impediments does not mean that Kerouac is resentful of the milieu. He believes that social terrain in general has a good intention in elevating human nature. In particular, Duluoz argues that "wars and social catastrophes arise from the cruel nature of bestial creation, and not from 'society', which after all has good intentions or it wouldnt [sic] be called 'society' would it?" (1968: 253). Duluoz is not spiteful or indifferent towards people but towards the modern reality. In fact, Kerouac articulates his skepticism of the age, regarding consumerism and capitalism, through Duluoz's painstaking pessimism when he and his friends sit around "with coffee cups and ashtrays and discuss decadence of the 'bourgeoisie' for days on end" (1968: 249). To further the argument, Duluoz refers to some existentialist writers like Jean-Paul Sartre and to W. H. Auden's Age of Anxiety (1947) (1968: 251), which is not a coincidence considering Duluoz exhibits an existential and desperate view of life, stating "I myself, as you can see from this whole insane of prose called a book, had been thru so much junk anyway you can hardly blame for joining in with the despairists of my time" (1968: 251); this may throw some light on Duluoz's distasteful time in the navy. Additionally, Auden's poem, an eclogue, deals with an individual's search for identity in an increasingly industrialized milieu:

For the others, like me, there is only the flash

Of negative knowledge, the night when, drunk, one

Staggers to the bathroom and stares in the glass

To meet one's madness, [...] (1947: 107) 
This poem clearly evinces a modern man's dilemma and his loss of identity in a world laden with labels. Similarly, Duluoz keeps searching for himself in an industrialized and consumer society, which blurs his vision. Duluoz sequesters himself and adopts a rhizomatic thinking through deterritorializing consumer society, social classes, educational system, and the capitalist state. This deconstruction gives way to Duluoz/Kerouac to become more nomadic whereof he is non-conformist to the norms of society and the instructions of the state especially when he critiques the institutionalized education in America.

Duluoz assesses the institutions of the state through expressing his dissatisfaction with the university curriculum. In particular, he explicitly questions the outcome of his education at Columbia University:

[W] hat did Columbia College offer me to study in the way of a course of theirs called Contemporary Civilization but the works of Marx, Engels, Lenin, Russel and other assorted blue printings that look good on blue paper and all the time the architect is the invisible monster known as Living Man? (Kerouac 1968: 79)

Duluoz, here, renounces how university instructors, "Living Man" or "the architect", appropriate the predecessors' ideologies, the well-known theorists and philosophers, and then foisting such institutionalized and subjective readings on their students without giving the latter freedom of forging their personal interpretations. Duluoz is perfectly convinced that the university suppresses polyvocality. Duluoz effectively answers the above question afterwards, professing that he "hadn't learned anything in college that was going to help [him] to be a writer anyway and the only place to learn was in [his] own mind in [his] own real adventures" (Kerouac 1968: 160).

Further, Duluoz encourages free thinking and questions dogmatic and institutionalized education:

When I said 'Adventurous Education', let the kid learn his own way, see what happens. You cant [sic] lead a horse to water. [...] so let the kid pick out exactly what he wants to do in order not to grow up into a big bore [...] the mind knows what it's doing better than the guile, because the mind flows, the guile dams up [...] And that's no guileless statement, however, and that's no Harvard lie (Kerouac 1968: 35).

This demonstrates Duluoz's palpable stand against pontifical education that is bestowed on students. Duluoz believes that a child or an individual should create his/her own path rather than relying on institutionalized universities to be of use to him/herself. To further his argument, he embraces auto-didacticism in order to reach the free or nomadic thinking he aspires to. Since Duluoz fancies widening his horizon and be more flexible in thinking rather than following dogmas offered by universities (Kerouac 1968: 21, 101), he constantly "evolve[s] plan[s] of selftutoring" (Kerouac 1968: 33). Auto-didacticism and self-tutoring are, for Duluoz, 
ways to detach oneself from the institutionalized education as a form of individuation; this reinforces the discourse of nomadic thinking and the war machine.

Alluding to Lord Byron is not a mere fortuity (Kerouac 1968: 56), for he is an epitome of the Promethean rebellion and idiosyncratic individualism that Kerouac idealizes. Most of his works and poems reverently enshrine personal freedom and non-conformity, especially in his play Manfred (1817), where the main character, Manfred, is disinclined to be submissive to any external power, regardless of its type or motives. Incensed by the Spirits, which remind him of his mortality, Manfred challenges them, expressing his rebellion:

The mind, the spirit, the Promethean spark,

The lightning of my being, is as bright,

Pervading, and far-darting as your own,

And shall not yield to yours, though cooped in clay! (1905: I, 90)

This signifies a conspicuous insubordination of Manfred towards the metaphysical power, which reflects Lord Byron's personal life as a rebel. Duluoz expresses similar spirit when he declares "the hell with these bigshot gangster football coaches, go after being an American writer, tell the truth, dont [sic] be pushed around by them or anybody else or any of their goons" (Kerouac 1968: 86). These "bigshot gangster football coaches" symbolize authoritarian leadership and governing forces that Duluoz/Kerouac grows to despise and disobey. He is quite convinced of the necessity to be individual: "I know what I am doing. Parents come, parents go, schools come, schools go, but what's an eager young soul going to do against the wall of what they call reality? Was Heaven based on the decisions of the aged fools? Did the elders tell the lamb who to bless?" (Kerouac 1968: 93). This indicates Duluoz's dissatisfaction with the traditions of society championed by the "aged fools". He tellingly deterritorializes religion itself when he questions whether the elders commanded the lamb/Christ who to bless; here, Duluoz particularly pinpoints the individualism of the lamb/Christ. Possessing Byronian and Thoreauvian spirit, Duluoz slowly emancipates his independent personality and converts into a Deleuzoguattarian nomad who indulges in free thinking and heterodoxy in the backdrop of a consumer and industrialized society.

In the sense of political nomadology, Kerouac critiques the army and demonstrates his inability to conform to its orders through the narrator Duluoz. The war machine is "irreducible to the State apparatus, to be outside its sovereignty and prior to its law: it comes elsewhere" (Deleuze and Guattari 1968: 352). This is featured when Duluoz enrolls in the navy and is perpetually demanded to follow orders:

I didnt [sic] mind the idea that I should be disciplined to death, not to smoke before breakfast, not to do this, that [...] this business of I cant [sic] smoke before breakfast and this other business of the admiral and his 
Friggin train walking around telling us that the deck should be so clean that we could fry an egg on it, if it was hot enough, just killed me. Who was this gentleman who had the nerve to tell me to wipe a speck off my foot? (Kerouac 1968: 145)

This is a quintessential example of how Duluoz, being in the navy, tries to uncover the irrationality and futility of those rules. He is acutely aware that these are the establishment's systematic methods of capturing the war machine by the state, on which Deleuze and Guattari comment that "the war machine is always exterior to the State, even when the State uses it, appropriates it" (1980: 243). Nevertheless, even if the war machine is captured or used by the state, it remains the 'other' and cannot be appropriated easily. Ultimately, Duluoz, the nomad, cannot simply condone to be apprehended under the navy's regimentation or to be held down by codes of the state, refusing to be among those despised by Thoreau in "Civil Disobedience": "The mass of men serve the State thus, not as men mainly, but as machines, with their bodies. They are the standing army, and the militia, jailers [...] [for] they put themselves on a level with wood and earth and stones" (1849: 263). Being simply a tool for the state is what Duluoz considers unacceptable, for it strips one from the freedom of thought and action.

When they are executing the marching army style, Duluoz lays his "gun down into the dust and just walked away from everybody forever more" (Kerouac 1968: 146). He then directly goes "to the Naval library to read some books and takes notes." They come and get him with nets (Kerouac 1968: 146). Not being able to explain his abhorrence to orders - although he has "highest IQ intelligence rating"- he is condemned to be in the psychiatric hospital (Kerouac 1968: 147). The navy is unable to discipline or explain Duluoz/Kerouac's idiosyncrasies and he is subsequently condemned to be mentally unstable. Thus, loyalty under dogmatic regimes, "entails adherence to a specific correspondence between one's perception of reality and recognition of authority, for a paranoid regime cannot assent to a plurality of realities" (Safaei 2020: 163). This emphasizes what Deleuze and Guattari ascertain about the war machine: "we certainly would not say that discipline is what defines a war machine: discipline is the characteristic requires of armies after the State has appropriated them" (1980: 358). Like the state with the war machine, the navy finds difficulties in indoctrinating Duluoz/Kerouac according to its rules. He becomes part of the metamorphosis of the war machine when he embraces his individuality and 'eccentricity'.

Inability to be disciplined is rather internal to the war machine for it is exterior to the state whether the former is captured or not. Instinctive diversion from the orders of the state or its institutions is also explained by Duluoz when he is interviewed by Dr. Ginsberg. He argues:

Now go ahead and put me up against a wall and shoot me, but I stand by that or stand by nothing [...], it's not that I refuse Naval discipline, not that I WONT [sic] take it, but I CANNOT [sic]. This is about all I have to 
say about my aberration. Not that I wont [sic], but that I cant [sic]" (Kerouac 1968: 154)

Duluoz is instinctively non-conformist which makes him the other or exterior to the state. He is more of 'becoming-nomad' than a citizen who conforms to the codes of the state. Consequently, the doctor is unable to explain Duluoz's independent or nomadic thinking. The latter further reiterates "I just cant [sic] take that business of telling me how to be day in and day out.[...] I cannot accept, or that is, I cannot live with your idea of discipline, I'm too much of a nut, and a man of letters" (Kerouac 1968: 154). His divergence from the state is exterior and this causes major problems to the latter. The state, in its turn, explains such behavior as simply madness when it fully fails to discipline him.

\section{Outsiderness and madness in On the Road}

On the Road is considered Kerouac's chef-d'ouevre for it epitomizes his literary style. The work is autobiographical, like many of Kerouac's other works, and it revolves around Sal Paradise, the narrator (Duluoz), who searches for literary materials through his constant cross-country travels with Dean Moriarty and many other Beat characters. It was published in 1957 and had been under literary radar since then. The novel deterritorializes many literary and cultural dogmas whereby it defines the discourse of the countercultural movement, which is social and political consciousness. Respectively, Ed D'Angelo contends that:

Kerouac was especially careful to distance himself from an aesthetics that might subordinate art to political ideology. But that does not mean that the beats believed that the transformation of consciousness they sought had no political or social implications. It merely means that, for them, political ideology follows consciousness, not the reverse. (2012: 227)

Kerouac's purpose is not political or social but rather literary; yet that is not the case in his novels for they palpably include political and social consciousness. In the introduction of On the Road, Ann Charters enunciates that "challenging the complacency and prosperity of postwar America hadn't been Kerouac's intent when he wrote his novel, but he had created a book that heralded a change of consciousness in the country" (1991: xxvii).

After the publication of On the Road, Charters argues, many "interviewers were not interested in 'Sal paradise' or Kerouac's life as a writer [...] they put down their pencils when he told them he came from a French-Canadian family" (1991: ix); this highlights Kerouac's otherness in an American society. Through writing On the Road, Kerouac was able to find his voice in searching "for a place as an outsider in America" (Charters 1991: xx). Although the narrator of On the Road, Salvatore Paradise, is partly American (Italian-American), there is still a sense of distinctness in him and in Dean Moriarty. Kerouac chooses the name of the latter in order to suggest that Neal Cassady, his actual friend, had an Irish 
ancestry (Charters 1991: xxi) (Irish uprisings). Adam Rachel demonstrates that Kerouac:

often described himself as an outsider within the privileged worlds of the Horace Mann School, Columbia University, and the New York literary scene. Surrounded by groups of rebellious male associates, his protagonists are plagued by the sense that they don't quite belong. (2009: 154)

In the novel, Sal, being a poor destitute writer, aligns himself with the underclass characters he constantly encounters on the road, from African Americans, Mexican fellahin, to hobos. This is an implicit acceptance of Kerouac's outsiderness as he humanizes the marginalized through Sal Paradise, Dean Moriarty and other Beat members. In this discourse, Deleuze and Guattari argue that the war machine comes from the outside of the state apparatuses (1980: 352 ) whilst Patton considers this machine of metamorphoses as distinct from and outside of the state (2000: 111).

All the characters, in On the Road, are from the underground whereof they continually travel or live freely, fending off social and political constraints. Sal refers to this point:

I was back on Times Square; and right in the middle of a rush hour, too, seeing with my innocent road-eyes the absolute madness and fantastic hoorair [sic] of New York with its millions and millions hustling forever for a buck among themselves, the mad dream — grabbing, taking, giving, sighing, dying, just so they could be buried in those awful cemetery cities beyond Long Island City. The high towers of the land - the other end of the land, the place where Paper America is born. (Kerouac 1957: 96)

In such criticism of consumer society and capitalism, Kerouac rarely cares about 'bourgeois' academic stylistics; so "hoorair" may well be his idiosyncratic neologism for 'horror'. Here, Kerouac/Sal depicts the way people succumb to a sanctioned version of reality that comes to exude an air of conformity and corporate thinking.

Further, by portraying the underground characters and aligning himself with them, Sal deterritorializes the American society and its codes. Adams specifies that "others themselves, his protagonists persistently identify with nonwhite people and others on the social margins, such as addicts, migrant laborers, vagrants, and prostitutes" (2009: 154-155). Notably, during his travels, Sal is constantly stranded with the marginalized ones; he, however, never complains of the situation. At one point, he hopes "for an SP freight to come along so [he] could join the grape-eating hobos and read the funnies with them" (Kerouac 1957: 92). At another point, he meets a bum whose name is Ghost and they get along whereby they become "bums together" (Kerouac 1957: 94). He feels that he belongs to the ostracized people as he is wondering around with Dean: 
We wandered around, carrying our bundles of rags in the narrow romantic streets. Everybody looked like a broken-down movie extra, a withered starlet; disenchanted stunt-men, midget auto-racers, poignant California characters with their-end-of-the-continent sadness, handsome, decadent, Casanova-ish men, puffy-eyed motel blondes, hustlers, pimps, whores, masseurs, bellhops - a lemon lot (Kerouac 1957: 154)

Mingling with the lower class is another form of deterritorialization of a 'standard' society or going beyond conventions. By extension, Sal and Dean are the metamorphoses of war machine as they are the outsiders and they accept being as such. In a time of harsh racial segregation, Sal goes so far as to wish he "could exchange worlds with happy, true-hearted, ecstatic Negroes of America" (Kerouac 1957: 164). Sal and Dean are the characters that do not abide by the conventions of the society such as having stereotypical ideas about the hobos, prostitutes, and the Mexican fellahins. Sal and Dean effectively align themselves with eccentric people that others may call as mentally ill or mad.

In psychiatry and psychoanalysis, madness is equivalent to what one may call mental illness that should be clinically treated. The APA Dictionary of Psychology states that madness is "an obsolete name for mental illness or for legal insanity". In Oxford dictionary, insanity is "a state of having a serious mental illness" or "crazy or stupid behavior that could be dangerous". Branimir M. Rieger demonstrates that "clinical madness [...] has largely negative reputation because of destructive, deviant behavior of mass murderers like Son of Sam, Ted Bundy and Jeffery Dahmer" (1994: 2). One of the most notable works about madness in the twentieth century is Foucault's Madness and Civilization: a History of Insanity in the Age of Reason where he gives an account of society's historical treatment of mentally ill individuals, beginning with the "ritual exiles" (1956: 8). He argues that the Age of Reason was a tragic era for the insane that were mostly confined and dehumanized only because they did not advocate bourgeois values or were considered a threat to the authorities (1956: 61-62). He adds that the age blindly "confined the debauched, spend-thrift fathers, prodigal sons, blasphemers, men who 'seek to undo themselves,' libertines. And through these parallels, these strange complicities, the age sketched the profile of its own experience of unreason." (1956: 61). Authorities, in fact, did not differentiate between the mentally ill individuals and the idiosyncratic ones (Foucault 1956: 61). Rieger maintains that "they replaced lepers as societal scapegoats" (1994: 2).

In literature and philosophy, however, madness is portrayed and studied quite differently. One of the main prolific works that discusses madness is Thus Spoke Zarathustra where Nietzsche advocates heterodox views, attesting that "No shepherd, and one herd! Everyone wanteth the same; everyone is equal: he who hath other sentiments goeth voluntarily into the madhouse" (1885: 11). Being different from the "herd" may lead one to be confined in a madhouse; conformity is the sane road for everyone as a way to be less conspicuous. Nietzsche also deconstructs the binary oppositions between sanity and madness in his work The Birth of Tragedy in which he contrasts between Apollo, a god of wisdom, and Dionysus, a god of madness, chaos, and excess (1872: 25-27). In this respect, one 
may fathom that Zarathustra can be a Dionysian figure that subverts values and beliefs of a structural society. Moreover, depiction of madness is quite diversified in literature, starting from William Shakespeare's Lear, to Fyodor Dostoevsky's the Underground Man and Herman Melville's the mad Ahab. Deleuze and Guattari, in their own way, wrote about mental illness (schrizophrenia) and its connection with capitalism, in Anti Oedipus, considering schizophrenia "as a positive process is inventive connection, expansion rather than withdrawal" (Massumi 1992: 1). Thereby, the psychological interpretation of mental illness is fairly dismantled in literature, especially in the twentieth century, since the center is vilified and the marginalized is brought to light. In this part, the focus of this study is to pinpoint the importance of the marginalized or the figure of 'madman' to the war machine. Notably, the 'madman' becomes the deterritorializing figure that overcomes the codes of the state. $\mathrm{He}$ is the non-conformist or the metamorphosis of the war machine that the state attempts to capture or else it aggravates the 'madman's situation by further ostracizing him.

A 'madman' is a problematic figure that the Beat Generation cannot help but align itself. In her article "Social Madness in Beat Generation Writing", Megan Reynolds argues that the mentally ill characters are championed by the Beat writers for they are exiled from society whereas they can offer new insights (2016: 86). Reynolds uses clinical madness and metaphorical counterpart interchangeably. This study, however, focuses largely on how this metaphorical and literary 'madness' can also be a segment of the Deleuzoguattarian war machine in a sense the 'mad ones' are metamorphoses of the nomadic assemblage. Rieger elucidates that "there are at least three ways in which 'mad' characters operate in a literary milieu" (1994: 7) and the second is the most relevant to the discourse of madness of this article. He sets forth that "nonconformist characters can rebel against a restrictive society by either appearing to be mad or actually going mad" (1994: 7). The Beats want to break away from the accustomed paradigms of the American mainstream through deterritorializing the social and stereotypical vision of the outsider. In fact, the Beat Generation takes 'madness' in celebratory form and hence extracting themselves further from the American society (Stirner's 'insurrection').

Kerouac depicts this unconventional 'mad' figure through Dean Moriarty and many other exiled characters. Sal Paradise, at first, is represented as someone who views these characters from afar, yet he cannot prevent himself from tracing their way of thinking and behaving:

I shambled after as I've been doing all my life after people who interest me, because the only people for me are the mad ones, the ones who are mad to live, mad to talk, mad to be saved, desirous of everything at the same time, $[\ldots]$ the ones who never yawn or say a commonplace thing, but burn, burn, burn like fabulous yellow roman candles exploding like spiders across the stars. (Kerouac 1957: 7) 
The mad individuals are the ones who challenge mainstream society. Rieger argues that "such 'mad' characters portray how society's dominant cultural values are often irreconcilable with the characters' lives and convictions" (1994: 8). These 'mad ones' are always burning or curious to know and hence "exploding like spiders across the stars" (Kerouac 1957: 7) as a rhizome, spreading everywhere. However, they are constantly looked on as outsiders or the anarchic groups that render society to chaos through their non-conformity. They are the Emersonian unconventional Man, Niezschean creator, and the Deleuzoguattarian nomadic non-conformists that become a part of a war machine within a capitalist America.

These incongruous individuals are ultimately from the marginalized classes which give them the freedom to expect less. Reynolds upholds that "the madman represents the embodiment of the Beat generation's anti-ideology because he illustrates a character so clearly outside of the mainstream's traditional way of thinking" (2016: 85). Using Deleuzoguattarian terms, the metaphorical madman is someone who maintains a nomadic thinking, which allows the Beat Generation to deterritorialize dogma and conventions. The madman, in On the Road, is Dean Moriarty, later renamed Cody Pomeray in Visions of Cody (1972), and many other Beat members such as Carlo Marx. In fact, from the beginning of the novel and upon seeing Dean for the first time, Sal's aunt "decide[s] that he was a madman" (Kerouac 1957: 5). Kerouac even mentions Dean in Visions of Cody through Cody Pomeray and his crazy attitude from his childhood $(1972: 64,90)$ to adulthood, calling him "absolutely crazy" (1972: 429).

Further, in On the Road, as part of his mad and eccentric attitude, Dean Moriarty steals cars for joy rides (Kerouac 1957: 9) and often drives crazily, getting in trouble with the police (Kerouac 1957: 191). In one of the rides, Sal describes it: "I could feel the road some twenty inches beneath me, unfurling and flying and hissing at incredible speed across the groaning continent with that mad Ahab at the wheel" (Kerouac 1957: 213). Analogously, Dean and Ahab possess untrammeled and often anarchical energy that might be regarded as a type of madness. Ahab's ship can be seen as Dean's car (in On the Road) that metaphorizes American society which entails that Dean, like Ahab, is indifferent to his friends' or society's opinions of him and his 'crazy' conduct. Reynolds suggests that "madness, although it signifies difference and results in exclusion from the mainstream society, serves as a sign of belonging for the Beat counterculture" (2016, 81). Sal proudly declares that Dean Moriarty "was BEAT - the root, the soul of Beatific" (Kerouac 1957: 177). Here, although Dean is constantly rejected or frowned upon, whether because of his 'madness' or poor state, Sal earnestly accepts and acknowledges Dean's importance as the epitome of optimism and happiness (Beatific). In Visions of Cody, Duluoz goes so far as to proclaim that Cody (Dean) is "an institution by himself" (Kerouac 1972: 455). In both quotes, the supposed madman, Cody/Dean, is recognized, by Kerouac/Sal, as the epitome of the Beat spirit who does not follow dogma where madness, rather than being an insult, becomes a form of celebratory eccentricity and individualism. 
Although, the narrator may seem a remote spectator who distances himself from the mad crowd, he, later on, willingly embraces this spiritual madness and integrates with the 'mad' crowd. Reynolds asserts that not only do "Dean's visions liberate [Sal] from America's repressive 1950s ideology, [but] they also have the power to illuminate meaning in a way that sane people cannot" (2016: 86). From the beginning, Sal informs the reader of him adhering to a new group: "They were like the man with the dungeon stone and the gloom, rising from the underground, the sordid hipsters of America, a new beat generation that I was slowly joining" (Kerouac 1957: 48). By being prodigal in crossing the borders and codes of the state or society, Sal becomes 'mad', caring to stay in contact with his crazy friends that liberate him from social structures and counting to tell their future children of "the raggedy madness and riot of [their] actual lives" (Kerouac 1957: 231). Moreover, people regard Sal and his friends as outlaws collectively: "People came out to stare at us but they never said a word and I think made mental notes of our descriptions and heights in case of future need" (Kerouac 1957: 215). The Beats are considered as a danger for their unaccustomed attitudes in a society that is used to conformity and static structures.

Sal and Dean, as rebellious characters, often run into problems with the police for their rampant driving and their eccentric appearance. When Sal is employed in Alcatraz as an officer, and puts the American flag unintentionally upside down, an officer claims " "you could go to jail for doing something like that.' The others nodded grimly. They were always sitting around on their asses; they were proud of their jobs. They handled their guns and talked about them. They were itching to shoot. Remi and me" (Kerouac 1957: 59). This indicates the police's readiness, and ultimately the state's, to handle a simple matter with violence. In another incident, an innocent citizen is arrested by the officer Sledge only because the former talks in a loud voice while Sledge finds it an opportunity to exert his power. Sal says "This is the story of America. Everybody's doing what they think they're supposed to do. So what if a bunch of men talk in loud voices and drink the night? But Sledge wanted to prove something" (Kerouac 1957: 61). Adequately, the metamorphosis of the war machine is always in danger of being captured or subdued by the state and in this case the police that asserts conformity.

Sal leaves his post and goes on adventurous trips with several Beat members. Throughout the book, there are several encounters with the police force that attempt to arrest Sal and his friends due to their appearance (Kerouac 1957: 109) and demeanor (Kerouac1957: 213). Deleuze and Guattari contend that between "despotic State and the juridical State containing a military institution, we see the flash of the war machine, arriving from without" (1980: 353). The war machine exudes a sense of outsiderness vis-a-vis regimentation and structured spaces, be it dictatorial or dogmatic states. This is applied to Sal and his friends who contravene the system of the state and society when it comes to conformity and ideology. In view of deterritorializing the state, Sal examines what the American police represent at one point: 
The American police are involved in psychological warfare against those Americans who don't frighten them with imposing papers and threats. It's Victorian police force; it peers out of musty windows and wants to inquire about everything, and can make crimes if the crimes don't exist to its satisfaction. (Kerouac 1957: 123)

This shows Sal's lack of faith in the state force or the police that simply want to manage the non-conformists and create a certain social confinement, which necessitates the metamorphosis of the war machine as the Beat members are constantly in danger of being captured. The Beat members who are unapologetically non-conformists pose a serious threat to the authority and society because of the latter's inability to regulate the Beats.

\section{Conclusion}

All in all, several unconventional characters in Kerouac's literary works, Vanity of Duluoz and On the Road, tend to be iconoclasts. The philosophies of the Beat Generation are often seen as rebellious and, hence, an imminent threat to society and the state, particularly in voicing their "rejection of the existing society" (Mettler 2015: 173). They represent, nonetheless, a phase in the metamorphosis of the war machine. These idiosyncratic and eccentric Beat members look for polyvocality and embrace their distinctness without creating an actual war within the state form. In other words, they simply deterritorialize social and political terrains through their atypical attitudes and philosophies. Sal Paradise, Dean Moriarty, Jack Duluoz, and Code Pomeray are Deleuze and Guattari's nomadic characters that keep overcoming the borders and walls of the state and the status quo through their constant questioning or challenging of the state's ideologies or the American mainstream codes. Effectively, while Duluoz and Sal are nomadic characters and both novels, Vanity of Duluoz and On the Road, are autobiographical, Kerouac may well be designated as a 'becoming nomad' who succeeds to deterritorialize capitalism from within through the nomadic war machine.

Sonia Kherif

University of Jordan

ORCID Number: 0000-0003-3512-9253

Email: Sonia.kherif1992@gmail.com

Samira Al-Khawaldeh

University of Jordan

ORCID Number: 0000-0001-9199-6330

Email: s.khawaldeh@ju.edu.jo 


\section{References}

Auden, W.H. (1947). The Age of Anxiety: A Baroque Ecologue, edited by Alan Jacobs. Princeton: Princeton UP.

Adam, Rachel. (2009). Continental Divides: Remapping the Cultures of North America.

Chicago: Chicago UP.

Byron, George Gordon. (1817). Manfred. In Ernest Hartely Coleridge (ed.), The Works of Lord Byron, 85-136. 13 vols. New York: Charles Scribner Sons, 1905.

Charters, Ann. (1991). 'Introduction'. In Jack Kerouac, On the Road, vii-xxxiii. UK: Penguin, Books.

D’Angelo, Ed. (2012). 'Anarchism and the beats'. In Sharin N. Elkholy (ed.), The Philosophy of the Beat, 277-242. Kentucky: Kentucky UP.

Deleuze, Gilles and Felix Guattari. (1972). Anti-Oedipus: Capitalism and Schizophrenia. Trans. Robert Hurley, Mark Seem, and Helen R. Lane. Minneapolis: Minnesota UP.

Deleuze, Gilles and Felix Guattari. (1980). A Thousand Plateaus: Capitalism and Schizophrenia. Trans. Brian Massumi, Minneapolis: Minnesota UP.

Emerson, Ralph Waldo. (1893). The American Scholar, Self-Reliance, Compensation. New York: American Book Company.

Elliott, Anthony. (1994). Pyschoanalytic Theory: An Introduction. London: Palgrave.

Fackenthal, Jeremy D. (2019).'Process philosophy and neo-materialism: Nomadic subjectivity and evanescing toward sustainability'. In Jeremy D. Fackenthal (ed.), Whitehead and Continental Philosophy in the TwentyFirst Century: Dislocations, 61-76. New York: Lexington Books.

Falla, Jeffery Bjorn. (2000). Becoming outsider: The cold war, masculinity, and the Beat Generation. Unpublished PhD Thesis, University of Minnesota, Minnesota, USA.

Foucault, Michel. (1956). Madness and Civilization: A History of Insanity in the Age of Reason. Translated by Richard Howard. New York: Routledge.

Hawes, Leonard C. (2015). New Philosophy of Social Conflict: Mediating Collective Trauma and Transitional Justice. London: Bloomsbury.

Kerouac, Jack. (1957). On the Road. UK: Penguin Books.

Kerouac, Jack. (1968). Vanity of Duluoz. UK: Penguin Books.

Kerouac, Jack. (1972). Visions of Cody. UK: Penguin Books. 
Massumi, Brian. (1992). A User's Guide to Capitalism ad Schizophrenia: Directions from Deleuze and Guattari. London: MIT Press.

Miller, Christopher L. (1993). 'The Postidentitarian predicament in the footnotes of a thousand plateaus: Nomadology, anthropology, and authority'. Diacritics, 23(3): 6-35.

Retrieved from JSTOR, www.jstor.org/stable/465398.

Mettler, Meghan Warner. (2015). "If I could drive you out of your mind': Anti-Rationalism andthe celebration of madness in 1960s counterculture'. Journal of Literary and Cultural Disability Studies, 9 (2): 171-187.

Mortenson, Erik. (2018). Translating the Counterculture: The Reception of the Beats in Turkey. Carbondale: Southern Illinois UP.

Newman, Saul. (2001). From Bakunin to Lacan: Anti-Authoritarian and the Dislocation of Power. UK: Lexington Books.

Nietzsche, Friedrich. (1881). Thus Spoke Zarathustra. Trans. Thomas Common. Hertfordshire: Wordsworth Classics.

Nietzsche, Friedrich. (1872) The Birth of Tragedy. Trans. Shaun Whiteside. London: Penguin Random House.

Patton, Paul. (2010). Deleuzian Concepts: Philosophy, Colonization, Politics. Stanford: Stanford UP.

Patton, Paul. (2000). Deleuze and the Political. New York: Taylor and Francis Group

Reynolds, Megan. (2016). 'Social madness in beat generation writing'. The Expositor: A Journal of Undergraduate Research in the Humanities. 8: 8099. Retrieved from http://digitalcommons.trinity.edu/eng_expositor/8

Rieger, Branimir M. (1994). 'Introduction'. In Branimir M. Rieger (ed.), Dionysus in Literature:Essays on Madness, 1-13. Bowling Green State University Popular Press: Bowling Green.

Safaei, Mohamed. (2020). 'The face of dictatorship in George Orwell's Nineteen Eighty-Four, Gabriel Garcia Marquez's The Autumn of the Patriarch, ad Mario LargasLlosa'sThe Feast of the Goat'. International Journal of ArabEnglish Studies, 20 (2): 149-168.

Stirner, Max. (1844).The Ego and His Own: The Case of the Individual against the Authority. Trans. Steven T. Byington. Ed. James T. Martin (2005). NY: Dover Publications, INC.

Thoma, Andrea. (2019). 'Vertigo of presence: Chantal Akerman's NOW, nomadic dwelling and the 'war machine' within the context of contemporary moving image works'. Journal of Visual Art Practice. Retrieved from https://doi.org/10.1080/14702029.2019.1676998 
Thoreau, Henry David. (1849). 'Civil disobedience'. Walden and Civil Disobedience.

Hertfordshire:

Wordsworth Classics.

https://dictionary.apa.org/madness

https://www.oxfordlearnersdictionaries.com/definition/english/madness?q=madne SS 